\section{Syndrom des raschen}

Zeitzonenwechsels

Helga Peter

Marburg, Deutschland

\section{Englischer Begriff}

time zone change syndrome

\section{Definition}

Veralteter Begriff für $\triangleright$ „Jetlag“ aus der ersten Version der ICSD von 1990.

Siehe auch $\triangleright$,Zirkadiane Schlaf-Wach-Rhythmusstörungen“. 